\title{
Assuring Quality Care: Exploring Strategies of Medicaid E\&D Waiver Providers
}

\section{Virginia \\ ingat}

Nancy Brossoie, Karen A. Roberto, Pamela B. Teaster*, and Anne Glass

Gerontology

Virginia Polytechnic Institute and State University, *University of Kentucky

\section{ABSTRACT}

Implementing quality assurance (QA) programs in unregulated noninstitutional settings remains a challenge for home and community-based service providers. A sample of 65 Elderly \& Disabled (E\&D) Waiver providers in Virginia were presented with eight problem scenarios commonly found in home-care services. Each of the respondents was able to identify strategies they would use to recognize and address each problem. Findings suggest providers currently use multiple mechanisms as part of their overall QA program. Discussion focuses on the strengths of using multiple approaches and on increasing provider awareness of complementary QA strategies and reducing the reliance on staff report as a major QA strategy.

\section{QUALITY SCENARIOS}

Based on earlier work by Kane, Frytak, and Eustis (1997), 8 scenarios were developed that demonstrated common conflicts between E\&D recipients and their providers.

unreliable worke

worker with a poor work ethic

worker with poor technical skills

- client/worker clash

client deteriorates despite care

client prefers a different schedule for aide visit

client has unstable mental health

- worker has unpleasant encounters with client's family member

PROVIDER PERCEPTIONS

Frequencies of Problem Scenarios

- neither very common nor very uncommon, but do exis

"worker has poor technical skills" and "worker has unpleasan

encounters with client's family member" were never selected as very common

"poor technical skills of staff" was selected by over $50 \%$ of the respondents as very uncommon

Likelihood of Identifying Problem Scenarios

- $79 \%$ likely to recognize problem

$16 \%$ unlikely to recognize "poor work ethic of staff"

Strategies Used to Recognize Problems

direct care staff, client, client's family, or supervisory staff were primary informants of problems over $50 \%$ of the time

formal QA mechanisms included satisfaction surveys

complaint mechanisms, and retrospective chart reviews

QA mechanism used in less than $10 \%$ of the scenarios as an identifying source

\section{QA STRATEGIES}

QA Strategies that Address Problem

Aggregate responses fit into 30 distinct categories for both client-oriented and worker-oriented probs needs of all eight problem scenarios. The most frequently mentioned strategies are presented.

Client Problem Scenarios (\%)

\begin{tabular}{|c|c|c|c|c|c|}
\hline & & & & & active chart audits (82 5\%) \\
\hline & $\begin{array}{c}\text { Client } \\
\text { Deteriorates }\end{array}$ & $\begin{array}{l}\text { Client } \\
\text { Prefers }\end{array}$ & $\begin{array}{l}\text { Client's } \\
\text { Unstable }\end{array}$ & & - $\quad$ client satisfaction surveys $(81.4 \%)$ \\
\hline & $\begin{array}{l}\text { Despite } \\
\text { Destes }\end{array}$ & $\begin{array}{l}\text { Drelers } \\
\text { Different }\end{array}$ & Mental & Unpleasant & - family caregiver satisfaction surveys (72.9\%) \\
\hline Agency Action & Care & Schedule & Health & 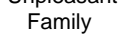 & performance outcome measures (52 6\%) \\
\hline uss with employee, client, \& & 16 & 4 & 11 & 19 & formal QI teams (35.1\%) \\
\hline
\end{tabular}

family

Discuss with family

Accommodate wishes if possible

Consult/ discuss with physician

Consult/ discuss with physician \& family

(a)

Investigate, by supervisory staf

Review/ alter care plan/ extra hours

Counsel employee/support staff

Assess

Assess safety

7
0
13
25
7
18
5
13
2
5
4

Total agencies responding

56

57

\begin{tabular}{cc}
11 & 33 \\
0 & 0 \\
11 & 0 \\
18 & 0 \\
20 & 5 \\
16 & 5 \\
6 & 9 \\
13 & 0 \\
4 & 12 \\
9 & 0 \\
6 & 4 \\
\hline
\end{tabular}

\begin{tabular}{|c|c|c|c|c|}
\hline & \multicolumn{4}{|c|}{ Worker Problem Scenarios (\%) } \\
\hline & & $\begin{array}{l}\text { Poor } \\
\text { Work }\end{array}$ & $\begin{array}{l}\text { Poor } \\
\text { Technical }\end{array}$ & $\begin{array}{l}\text { Poor } \\
\text { Client/ }\end{array}$ \\
\hline gency Action & $\begin{array}{c}\text { Unreliable } \\
\text { Worker }\end{array}$ & $\begin{array}{l}\text { Ethic of } \\
\text { Staff }\end{array}$ & $\begin{array}{l}\text { Skills of } \\
\text { Staff }\end{array}$ & $\begin{array}{l}\text { Worker } \\
\text { Clash }\end{array}$ \\
\hline
\end{tabular}

\section{Discuss with employee}

Discuss with employee \& clien

Warning/ discipline

Progressive disciplinary actio

Restaff case/ replace aid

Dischar

Training

improvement/ plan

Check documentation/scheduling

Follow up/monitor/ closer supervision

Investigate, handled by supervisory staff

Counsel employee/support staff

wor

Total agencies responding 57
FORMAL QA MECHANISMS

Overall, $86.2 \%$ of the respondents indicated that they incorporated ormal QA mechanisms in their business practices.

on-site supervision $(94.7 \%)$

formal complaint mech

\section{CONCLUSIONS}

Findings suggest that E\&D Waiver providers

- use QA mechanisms in their businesses, but may not have a comprehensive quality assurance plan in place

- utilize and support a basic communication component to meet their QA needs and maintain the quality of their services

Findings also indicate that

- less than $10 \%$ of the agencies reported using a complaint mechanism as a response to the problem scenarios presented

- clients and their family members could benefit from a wellpublicized formal complaint mechanisms at both the agency and state leve

- there is a gap between what agencies understand a QA program to be and how to utilize it effectively

- providers may benefit from additional training in the principles of QA, identifying QA mechanisms, and developing a comprehensive and effective quality improvement program that meets their agency's needs

\section{REFERENCE}

Kane, R. A.., Frytak, J., \& Eustis, N. N. (1997). Agency approaches to common quality problems in home care: A scenario study. Home Health Care Services Quarterly, 16, 21-40. 